\title{
Effects of nutrients and turbulence on the production of transparent exopolymer particles: a mesocosm study
}

\author{
M. L. Pedrotti ${ }^{1, *}$, F. Peters ${ }^{2}$, S. Beauvais ${ }^{1}$, M. Vidal ${ }^{3}$, J. Egge ${ }^{4}$, A. Jacobsen ${ }^{4}$, C. Marrasé ${ }^{2}$ \\ ${ }^{1}$ Marine Microbial Ecology Group, Laboratoire d'Océanographie de Villefranche, CNRS-UMR 7093, BP 28, \\ 06234 Villefranche-sur-mer, France \\ ${ }^{2}$ Institut de Ciències del Mar, CMIMA (CSIC), Passeig Marítim de la Barceloneta 37-49, 08003 Barcelona, Catalunya, Spain \\ ${ }^{3}$ Departament d'Ecology, Universitat de Barcelona, Barcelona, Spain \\ ${ }^{4}$ Department of Fisheries and Marine Biology, University of Bergen, HIB, 5020 Bergen, Norway
}

\begin{abstract}
The production of transparent exopolymer particles (TEP) in response to several environmental variables was studied in 2 mesocosm experiments. The first (Expt 1) examined a gradient of 4 nutrient levels; the second (Expt 2) examined different conditions of silicate availability and zooplankton presence. Tanks were separated in 2 series, one subjected to turbulence and the other not influenced by turbulence. In tanks with nutrient addition, TEP were rapidly formed, with net apparent production rates closely linked to chl a growth rates, suggesting that phytoplankton cells were actively exuding TEP precursors. High nutrient availability increased the absolute concentration of TEP; however, the relative quantity of TEP produced was found to be lower, as TEP concentration per unit of phytoplankton biomass was inversely related to the initial nitrate dose. In Expt 1, an increase in TEP volume ( 3 to $48 \mu \mathrm{m}$ equivalent spherical diameter) with nutrient dose was observed; in Expt 2, both silicate addition and turbulence enhanced TEP production and favored aggregation to larger TEP $(>48 \mu \mathrm{m})$. The presence of zooplankton lowered TEP concentration and changed the size distribution of TEP, presumably by grazing on TEP or phytoplankton. For lower nutrient concentrations, the ratio of particulate organic carbon (POC) to particulate organic nitrogen (PON) followed the Redfield ratio. At higher nutrient conditions, when nutrients were exhausted during the post-bloom, a decoupling of carbon and nitrogen dynamics occurred and was correlated to TEP formation, with a large flow of carbon channeled toward the TEP pool in turbulent tanks. TEP accounted for an increase in POC concentration of $50 \%$ in high-nutrient and turbulent conditions. The study of TEP dynamics is crucial to understanding the biogeochemical response of the aquatic system to forcing variables such as nutrient availability and turbulence intensity.
\end{abstract}

KEY WORDS: Transparent exopolymer particles - TEP production · Phytoplankton · Particulate organic carbon $\cdot$ POC $\cdot$ Turbulence $\cdot$ Nutrients $\cdot$ Mesocosms

Resale or republication not permitted without written consent of the publishe

\section{INTRODUCTION}

Transparent exopolymer particles (TEP) are nonliving organic particles formed abiotically from acid polysaccharides released as dissolved and colloidal matter from phytoplankton and bacteria (Zhou et al. 1998, Passow 2000). TEP have a size ranging between 1 and hundreds of micrometers and are found in high concentrations in a variety of marine environments
(Alldredge et al. 1993). The TEP pool has an important effect on the carbon (C) flux of the pelagic zone by accelerating the sedimentation of non-TEP particles through coagulation-aggregation processes (Logan et al. 1995, Passow \& Alldredge 1995a, Prieto et al. 2002). Owing to their high $\mathrm{C}$ content and abundance, TEP themselves can directly contribute to $\mathrm{C}$ fluxes, representing a mechanism for the selective sequestration of $\mathrm{C}$ in deep water (Beauvais et al. 2003, Engel et al. 2004). 
Some factors are known to be important in the dynamics of TEP production, such as the productivity and trophic state of the system (Mari et al. 2001, Carrias et al. 2002, Passow 2002). In natural environments, high concentrations of TEP have been associated with phytoplankton blooms, in particular when diatoms are dominant (Passow \& Alldredge 1995a, Passow et al. 2001). TEP have also been observed during blooms dominated by other phytoplankton groups such as dinoflagellates (Passow \& Alldredge 1994, Berman \& Viner-Mozzini 2001), cyanobacteria (Grossart \& Simon 1997), or prymnesiophytes such as Phaeocystis sp. and Emiliana huxleyi (Engel 2000, Reigstad et al. 2000, Mari et al. 2005). In some cases co-variation has been observed between TEP and phytoplankton biomass in terms of chl a (Passow \& Alldredge 1995b, Beauvais et al. 2003, Radic et al. 2005, Prieto et al. 2006). However, the production rate of TEP is thought to be speciesspecific (Berman \& Viner-Mozzini 2001, Passow 2002) and changes in the physiological state of cells and in environmental conditions should then influence the quantity and quality of phytoplankton-derived organic matter, which will have an effect on TEP production (Schuster \& Herndl 1995, Underwood et al. 2004, Claquin et al. 2008). Turbulence and the associated shear is another factor that affects the dynamics of TEP (Beauvais et al. 2006). Turbulence is known to influence the structure of the pelagic trophic web and the dynamics of the particles suspended within, and exported from, the water column (Peters \& Marrasé 2000, Peters et al. 2002). This includes top-down processes such as shifts in contact rates between particles (MacKenzie \& Kiørboe 1995) and bottom-up processes such as the increase in nutrient flux to cells (Savidge 1981, Kiørboe 1993, Moeseneder \& Herndl 1995, KarpBoss et al. 1996, Peters et al. 2006). The availability of nutrients has been shown to affect the stoichiometry of organic matter and nutrient uptake, and the composition of particulate organic matter (POM) is affected by turbulence (Maar et al. 2002). In laboratory experiments, TEP formation is likely accelerated by turbulence (Schuster \& Herndl 1995).

Here we present a study examining the effects of a nutrient gradient on TEP production in turbulent and non-turbulent conditions. This work was performed in the framework of the EC-ELOISE-NATP project $(\mathrm{Nu}-$ trient Dynamics mediated through Turbulence And Plankton Interactions). Results from a previous experiment (WS1) in which we examined the effects of different levels of turbulence on TEP dynamics showed that turbulence affected TEP production by increasing coagulation processes (Beauvais et al. 2006). Turbulence promotes TEP aggregation and, depending on its intensity, modulates $\mathrm{C}$ export by maintaining the TEP pool at the surface or enhancing sedimentation.
In the present mesocosm experiment (WS2), the objectives were to investigate (1) the production of TEP under a gradient of nutrients and at different conditions of silicate availability and zooplankton abundance, (2) how turbulence interacts with these factors, and (3) the way TEP dynamics affect $C$ fluxes in a system modulated by interactions between nutrients, turbulence, and plankton.

\section{MATERIALS AND METHODS}

Experimental setup. The present work was conducted between 16 June and 7 July 2002 at the Marine Biological Station, University of Bergen, Norway. Twelve land-based tanks $\left(2.6 \mathrm{~m}^{3}, 1.5 \mathrm{~m}\right.$ diameter, $1.5 \mathrm{~m}$ depth, open to the air) were filled with seawater collected at $5 \mathrm{~m}$ depth and filtered through a $250 \mu \mathrm{m}$ mesh to remove large organisms and macro-detritus (except for the zooplankton treatment in Expt 2; Table 1). Tanks were placed inside larger enclosures filled with circulating seawater to maintain an approximate in situ temperature. Two series of tanks were prepared. In 1 series, turbulence ( $\mathrm{T}$ ) was generated with 2 vertically oscillating grids at an energy dissipation rate of ca. $5 \times 10^{-2} \mathrm{~cm}^{2} \mathrm{~s}^{-3}$, while another series was not subjected to artificial turbulence (S). The grids were made of Plexiglas that allowed $95 \%$ penetration of photosynthetically active radiation (PAR). The grids had a bar width of $5 \mathrm{~cm}$, a mesh size of $10 \mathrm{~cm}$, and a stroke length of $40 \mathrm{~cm}$, centered at 45 and $105 \mathrm{~cm}$ from the bottom. Turbulence intensities were calculated from velocitytime series measured with an acoustic Doppler velocimeter, using the method of linear regression described in Stiansen \& Sundby (2001).

Two mesocosm experiments were performed successively. The first (Expt 1) consisted of 2 parallel gradi-

Table 1. Experimental design and terminology of the 2 experiments. In turbulent tanks the level of turbulence was ca. $5 \times$ $10^{-2} \mathrm{~cm}^{2} \mathrm{~s}^{-3}$. Note that S8 and T8 experimental conditions of Expt 1 and $\mathrm{Si}$ and TSi of Expt 2 are equivalent treatments

\begin{tabular}{|lccc|}
\hline $\begin{array}{l}\mathrm{N}^{-\mathrm{NO}_{3},} \mathrm{P}-\mathrm{PO}_{4}, \\
\mathrm{Si}-\mathrm{SiO}_{3}(\mu \mathrm{M})\end{array}$ & $\begin{array}{c}\text { Still } \\
\text { tanks }\end{array}$ & $\begin{array}{c}\text { Turbulent } \\
\text { tanks }\end{array}$ & Zooplankton \\
\hline Expt 1 & & & \\
No addition & $\mathrm{S} 0$ & $\mathrm{~T} 0$ & - \\
$4,0.25,8$ & $\mathrm{~S} 4(\mathrm{~A}, \mathrm{~B}, \mathrm{C})$ & $\mathrm{T} 4(\mathrm{~A}, \mathrm{~B}, \mathrm{C})$ & - \\
$8,0.50,16$ & $\mathrm{~S} 8$ & $\mathrm{~T} 8$ & - \\
$16,1.0,32$ & $\mathrm{~S} 16$ & $\mathrm{~T} 16$ & - \\
& & & \\
Expt 2 & & & - \\
$8,0.5,0$ & $\mathrm{~B}$ & $\mathrm{~T}$ & + \\
$8,0.5,0$ & $\mathrm{Z}$ & $\mathrm{TZ}(\mathrm{A}, \mathrm{B})$ & - \\
$8,0.5,16$ & $\mathrm{Si}$ & $\mathrm{TSi}$ & + \\
$8,0.5,16$ & $\mathrm{ZSi}$ & $\mathrm{TZSi}(\mathrm{A}, \mathrm{B})$ & + \\
\hline
\end{tabular}


ents in nutrient levels. At the onset of the experiment, increasing concentrations of nutrients were added: 0 , 4,8 , and $16 \mu \mathrm{M}$ of nitrate $\left(\mathrm{N}-\mathrm{NO}_{3}\right)$; phosphate $\left(\mathrm{P}-\mathrm{PO}_{4}\right)$ supplied at the Redfield ratio; and silicate $(\mathrm{Si})$ at twice the nitrate dose. Tanks were separated in 2 series: T0, T4, T8, and T16 for turbulent treatment; and S0, S4, S8, and S16 for still ones (Table 1). Treatments S4 and T4 were triplicated $(A, B, C)$. The experiment lasted for $6 \mathrm{~d}$ for the first 3 nutrient levels and over a period of $12 \mathrm{~d}$ in tanks where $16 \mu \mathrm{M}$ of nitrate was added. The second experiment (Expt 2) tested the effects of presence/ absence of silicate (Si), zooplankton (Z), and turbulence $(\mathrm{T})$. Initial addition of nitrate and phosphate was $8 \mu \mathrm{M}$ and $0.5 \mu \mathrm{M}$ respectively since this level resulted in a significant chlorophyll peak within $6 \mathrm{~d}$ in Expt 1. Two of the treatments were duplicated, designated TZSi.A and TZSi.B, and TZ.A and TZ.B. It is worthwhile to note that S8 and T8 experimental conditions of Expt 1 and the Si and TSi ones of Expt 2 were identical treatments (Table 1), which allowed us to investigate the importance of the initial plankton community on TEP dynamics.

Sampling procedures. Integrated samples were taken daily at 09:00 h from each tank in plastic carboys (samples for nutrients and chl a were taken twice a day on the first $3 \mathrm{~d}$ ). Sub-samples were collected for the determination of dissolved inorganic nutrients, suspended chl $a$, particulate organic C (POC), particulate organic nitrogen (PON), and TEP. Dissolved inorganic nutrient concentrations were analyzed using standard methods (Strickland \& Parsons 1972). Samples for chl a were filtered onto different porosity filters extracted in $10 \mathrm{ml} 90 \%$ acetone for $24 \mathrm{~h}$ and analyzed on a Turner Design Fluorometer (Parsons et al. 1984). Samples for POC and PON were filtered onto pre-combusted Whatman GF/F glass-fiber filters and measured in a Carlo Erba analyzer after exposing the filters to $\mathrm{HCl}$ fumes (Grasshoff et al. 1999).

TEP determination and $\mathbf{C}$ content. Several sample aliquots of different volumes $(5,10$, and $15 \mathrm{ml})$ were gently filtered through $0.2 \mu \mathrm{m}$ white Nuclepore filters under constant and low pressure. Material retained on the filter was stained with $500 \mu$ l of an aqueous solution of $0.06 \%$ acetic acid $(\mathrm{pH} 2.5)$ and $0.02 \%$ Alcian blue 8GX (Passow \& Alldredge 1994). Since Alcian blue, a specific stain for negatively charged polysaccharides, may precipitate in the presence of salts, the filters were rinsed with distilled water between consecutive filtrations, and the dye was tested before each experiment with artificial seawater at $38.2 \%$ (SIGMA), twice filtered onto a $0.2 \mu \mathrm{m}$ filter. Blanks did not show a significant presence of TEP. After the staining procedure, the filters were mounted directly on a white slide (Cyto-Clear). TEP were observed through an Axiophot-Zeiss microscope, by means of a semi-automatic image-analysis system. The TEP perimeter was traced semi-automatically and the equivalent spherical diameter (ESD) of an individual TEP was then calculated from area measurements assuming the geometry of a sphere. Counts were binned by ESD into 15 logarithmic size classes between 1 and $135 \mu \mathrm{m}$. A minimum of 600 TEP for each sample were counted and sized at 3 successive magnifications $(100 \times, 200 \times, 400 \times)$, to cover the entire size spectra (Beauvais et al. 2003).

Particle-size distributions of TEP were fitted to the power-law function usually used to describe the particle-size spectra of ocean particles (Sheldon et al. 1972), following the equation from McCave (1984):

$$
\mathrm{d} N / \mathrm{d}\left(d_{\mathrm{p}}\right)=k d_{\mathrm{p}}^{\delta}
$$

where $\mathrm{d} N$ is the number of particles per unit volume, with a diameter ranging $d_{\mathrm{p}}$ to $\left[d_{\mathrm{p}}+\mathrm{d}\left(d_{\mathrm{p}}\right)\right]$, and $d_{\mathrm{p}}$ is the projected spherical encased diameter. The constant $k$ depends on particle concentration, and the spectral slope $\delta$ relates the abundance of small to large particles. $k$ and $\delta$ were calculated using linear regression of $\log \left[\mathrm{d} N / \mathrm{d}\left(d_{\mathrm{p}}\right)\right]$ versus $\log \left(d_{\mathrm{p}}\right)$. TEP concentrations were given in total numbers $\mathrm{ml}^{-1}$ and in total volume (ppm). For comparison of different treatments, the concentration of TEP belonging to a given size class was standardized by the width of this size class: TEP

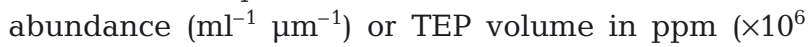
$\left.\mu \mathrm{m}^{3} \mu \mathrm{m}^{-1}\right)$.

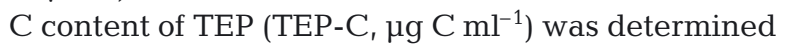
from TEP size-frequency distribution using the sizedependent relationship proposed by Mari (1999):

$$
\text { TEP-C }=0.25 \Sigma_{i} n_{i} r_{i}^{2.55}
$$

where $n_{i}$ is the concentration of particles in size class $i$ and $r_{i}$ is the TEP radius $(\mu \mathrm{m})$ in the same size class.

The total C content of phytoplankton was calculated from an adjusted bulk $\mathrm{C}$ :chl a ratio for each experiment. The constraint was that this ratio should give, on average, an autotrophic $\mathrm{C}$ biomass equal to the sum of phytoplankton biomass from cell volume estimates. A further constraint was set so that total plankton biomass (autotrophic and heterotrophic) estimated from cell volumes could not exceed the value of POC. The C:chl a (weight:weight) ratio was 115 in Expt 1 and 64 in Expt 2.

The effect of turbulence and nutrient dose on TEP concentrations was statistically compared using analysis of covariance (ANCOVA) with sampling times as a covariate. Differences between the slopes of regression lines of size distributions of TEP were statistically compared with logarithmic transformations in the data. The data for Time 0 was not included in the analysis, as treatments had no time to affect the different variables. Post hoc statistics were also performed. The effect of turbulence on biological variables was tested with 
ANOVA and the Kruskal-Wallis test. Potential relationships between biological variables were tested using Pearson's correlation coefficient or linear regression. All statistical analyses were done with XLSTAT. Significance was considered for $\mathrm{p}<0.05$.

\section{RESULTS}

\section{Nutrient dynamics}

In Expt 1, before nutrient addition, the concentrations of dissolved inorganic $\mathrm{N}-\mathrm{NO}_{3}, \mathrm{P}-\mathrm{PO}_{4}$, and silicate were low $(0.65,0.07$, and $0.23 \mu \mathrm{M}$, respectively), corresponding to a post-bloom period. Following nutrient addition (Fig. 1A), the concentration of nitrate decreased; about $90 \%$ of nitrates were consumed within $4 \mathrm{~d}$ in all tanks. In S4, T4, S8, and T8 tanks, by Day 6 the nitrate concentration was near the limit of detection. In Tanks S16 and T16, the concentration reached $0.25 \mu \mathrm{M} \mathrm{N}-\mathrm{NO}_{3}$ by the end of the experiment. Phosphate concentration decreased within $3 \mathrm{~d}$, remaining relatively low in all tanks (Fig. 1A), and silicate was not consumed. In Expt 2, before nutrient addition, $\mathrm{N}-\mathrm{NO}_{3}$, $\mathrm{P}_{-} \mathrm{PO}_{4}$, and silicate concentrations were $0.53,0.04$, and $1.13 \mu \mathrm{M}$, respectively. After the addition of $8 \mu \mathrm{M} \mathrm{N}$ $\mathrm{NO}_{3}$ (Fig. 1B), the concentration rapidly decreased (average of $0.1 \mu \mathrm{M}$ on Day 4) and became undetectable on Day 6 in all tanks. Likewise, phosphate concentrations had decreased on Day 4 to an average of $0.08 \mu \mathrm{M}$ and became undetectable on Day 6 in turbulent tanks where zooplankton were present (Fig. 1B). In tanks enriched with $16 \mu \mathrm{M}$ of silicate, in turbulent tanks (TSi, TZSi) all silicates were consumed, while in the still tanks ( $\mathrm{Si}, \mathrm{ZSi}$ ) they were not (on Day 6 , the silicate concentration was about $10 \mu \mathrm{M}$ ).

\section{Phytoplankton dynamics}

Small autotrophic plastidic flagellates and Synechococcus-like cyanobacteria initially dominated Expt 1 and peaked on Day 3 (average concentration of $3.8 \times$ $10^{7}$ and $5.2 \times 10^{8}$ cells $1^{-1}$, respectively). At the start of the experiment, diatoms were present in relatively low numbers $\left(2.7 \times 10^{5}\right.$ cells $\left.1^{-1}\right)$. Fig. $1 \mathrm{C}$ shows chl a concentration in different treatments over the course of the experiment. Before nutrient addition, total chl a concentration was $0.99 \pm 0.19 \mu \mathrm{g} \mathrm{l}^{-1}$. In tanks without addition of nutrients (S0, T0), chl a increased slightly to reach a maximum concentration of $1 \mu \mathrm{g} \mathrm{l}^{-1}$ on Day 1 . In S4 and T4 tanks, a peak in chl a concentration of 2.72 and $2.93 \mu \mathrm{g} \mathrm{l}^{-1}$ occurred on Day 2 for still and turbulent tanks, respectively. In S8, T8, and S16 tanks, a peak in
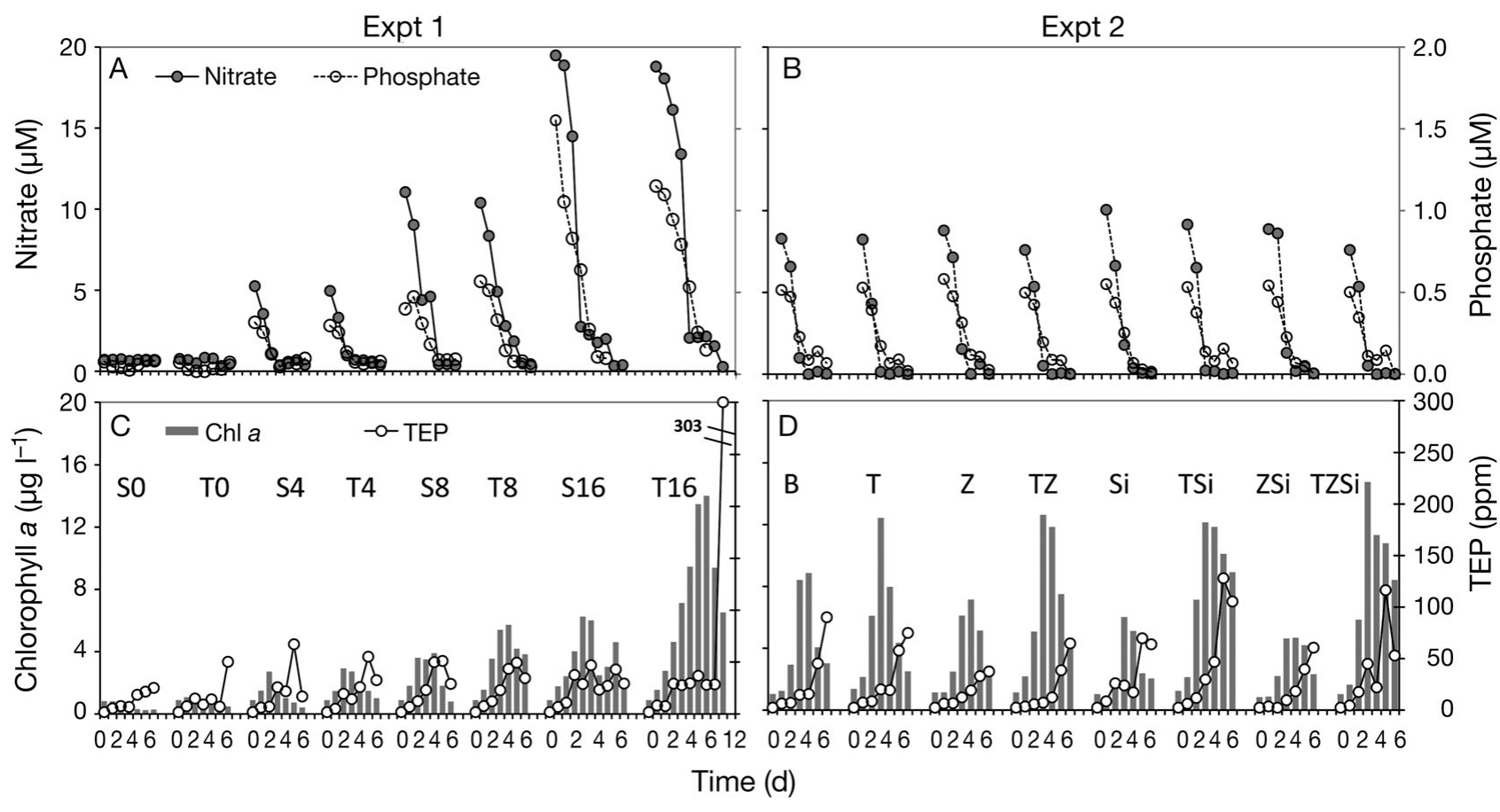

Fig. 1. Temporal changes in $(\mathrm{A}, \mathrm{B})$ nitrate and phosphate and $(\mathrm{C}, \mathrm{D}) \mathrm{chl} a$ and transparent exopolymer particle (TEP) concentrations in different treatment tanks during Expts $(A, C) 1$ and $(B, D) 2$. Samples for nutrients and chl a were taken twice a day on the first $3 \mathrm{~d}$ of the experiments. The last point for Tanks T16 (C) lies outside the axis scale and therefore the number 303 is in the upper right corner. See Table 1 for tank abbreviations 
chl a (3.9, 5.73, and $6.25 \mu \mathrm{g} \mathrm{l}^{-1}$, respectively) occurred on Day 4. In T16, the exponential growth of phytoplankton lasted for $\sim 7 \mathrm{~d}$ until peaking at $14.01 \mu \mathrm{g} \mathrm{chl} \mathrm{a}$ $\mathrm{l}^{-1}$. Chl a concentration was significantly higher in turbulent tanks (Kruskal-Wallis test, $\mathrm{p}<0.05$ ). In S0, T0, S4, T4, and S8 tanks, small phytoplankters $(<5 \mu \mathrm{m})$ comprised the largest fraction $(63 \pm 4.9 \%)$ of the autotrophic $\mathrm{C}$ during all the experiments. In T8, S16, and T16 tanks, after the chl a peak, a shift in the size composition of phytoplankton occurred, with $>70 \%$ of the autotrophic C composed of cells $>20 \mu \mathrm{m}$ in size. The mean value of the percentage of diatom $\mathrm{C}$ in total autotrophic $\mathrm{C}$ during the experiment varied from $19 \%$ for S0 to $56 \%$ for T16 (Table 2).

In Expt 2, the initial phytoplankton was also made up of plastidic flagellates $\left(0.5 \times 10^{7}\right.$ cells $\left.1^{-1}\right)$ and Synechococcus spp. $\left(2.1 \times 10^{8}\right.$ cells $\left.1^{-1}\right)$ but at lower concentrations than in Expt 1. The chl a concentration was $1.12 \pm 0.14 \mu \mathrm{g} \mathrm{l}^{-1}$ before nutrient addition, then increased markedly in turbulent tanks, with a peak of $14.76 \mu \mathrm{g}^{-1}$ on Day 3 in tanks with the addition of silicates and presence of zooplankton (TZSi; Fig. 1D). Up to Day 3 , the small cells $(<5 \mu \mathrm{m})$ represented an average of $50 \%$ of the total autotrophic biomass in all tanks. By Day 4, diatoms became abundant in the tanks enriched with silicate. In turbulent tanks (TSi, TZSi), a shift occurred in the size composition of phytoplankton, with $>80 \%$ of the total autotrophic biomass composed of cells $>20 \mu \mathrm{m}$ in size. By Day 6, a peak in diatom biomass $\left(675 \mu \mathrm{gC} \mathrm{l}^{-1}\right)$ was observed in TZSi tanks. The mean value of the percentage of diatom $\mathrm{C}$ in total autotrophic $\mathrm{C}$ were higher in tanks enriched

Table 2. Diatom carbon (C) content in total autotrophic carbon for the different experimental conditions of Expts 1 and 2 . Mean values (\%) over the study period. See Table 1 for tank abbreviations. Si: silicate

\begin{tabular}{|c|c|c|c|}
\hline \multicolumn{4}{|l|}{ Expt 1} \\
\hline Tank & till $\overline{\text { Diatom C (\%) }}$ & \multicolumn{2}{|c|}{$\begin{array}{l}\text { Turbulent } \\
\text { Tank } \quad \text { Diatom } \mathrm{C}(\%)\end{array}$} \\
\hline So & 19 & T0 & 40 \\
\hline $\mathrm{S} 4$ & 41 & $\mathrm{~T} 4$ & 31 \\
\hline S8 & 26 & T8 & 27 \\
\hline S16 & 55 & T16 & 56 \\
\hline Average & $28 \pm 11$ & Average & $39 \pm 9$ \\
\hline \multicolumn{4}{|l|}{ Expt 2} \\
\hline \multicolumn{2}{|c|}{ - Without Si addition _ _ } & \multicolumn{2}{|c|}{ — With Si addition — } \\
\hline Tank & Diatom C (\%) & Tank & Diatom C (\%) \\
\hline B & 30 & $\mathrm{Si}$ & 79 \\
\hline $\mathrm{T}$ & 21 & TSi & 54 \\
\hline $\mathrm{Z}$ & 34 & $\mathrm{ZSi}$ & 47 \\
\hline $\mathrm{TZ}$ & 33 & TZSi & 58 \\
\hline Average & $29 \pm 4$ & Average & $59 \pm 9$ \\
\hline
\end{tabular}

with silicate $(59 \pm 9.52 \%)$ than in non-enriched tanks $(29 \pm 4.14 \%$; Table 2$)$ and in general the contribution of diatoms to total autotrophic $\mathrm{C}$ was higher in Expt 2 than in Expt 1.

\section{TEP concentration and production rates}

Expt 1

Variations in TEP volume concentration (ppm) during the experiment for the different treatments are shown in Fig. 1C. Before nutrient addition, TEP concentration was $1.78 \mathrm{ppm}$ and it increased in all tanks during the exponential phytoplankton growth. In tanks without nutrient addition, TEP volume increased up to Day 6, reaching a concentration of $50 \mathrm{ppm}$ in turbulent tanks. In tanks enriched with nutrients, the volume of TEP increased up to Day 5, reaching an average concentration of $50 \mathrm{ppm}$; then TEP concentration decreased on Day 6 in all tanks except in T16 where the maximum TEP volume (303 ppm) occurred at the end of the experiment on Day 12 (Fig. 1C). The same trends were observed for TEP-C $;$ its concentration increased from $39.1 \mu \mathrm{g} \mathrm{C}^{-1}$ before nutrient addition to up to

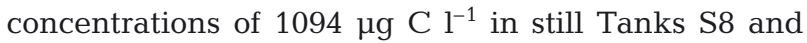
$5260 \mu \mathrm{g} \mathrm{C}^{-1}$ in T16 tanks on Day 12 (Table 3). Fig. 2 shows TEP-C ( $\mu \mathrm{g} \mathrm{C}^{-1}$ ) normalized to the total $\mathrm{C}$ content of phytoplankton ( $\mu \mathrm{g} \mathrm{C}^{-1}$ ). The ratio TEP:chl a was higher in tanks with no addition of nutrients and decreased with the nutrient doses added. The general trend was that this ratio was higher after the phyto-

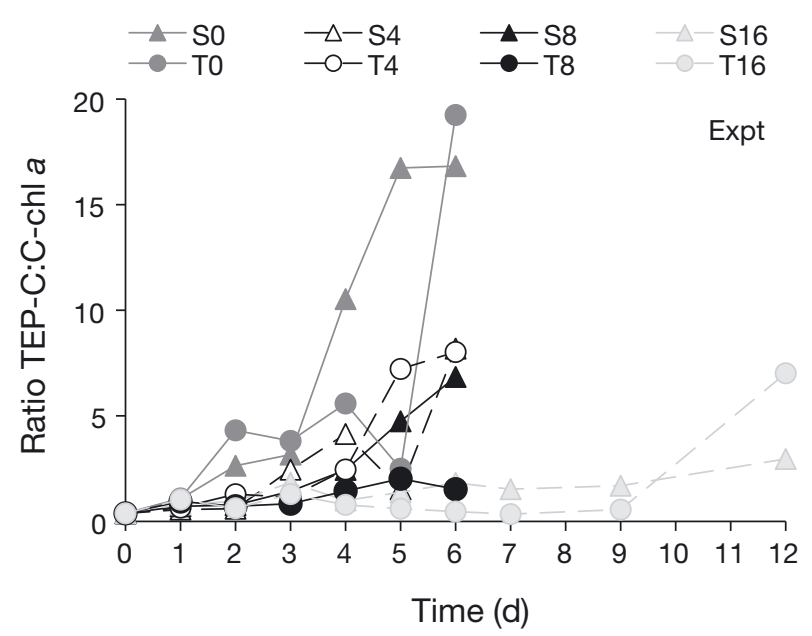

Fig. 2. Carbon (C) content of transparent exopolymer particles

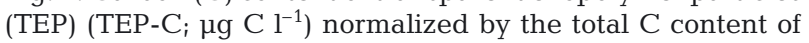
phytoplankton (C-chl $a_{i} \mu \mathrm{g} \mathrm{C} \mathrm{l}^{-1}$ ) during Expt 1 in tanks with no addition and increased addition of nutrients. Organic $\mathrm{C}$ due to phytoplankton was calculated using a C:chl a ratio of 115 (see 'Material and methods'). See Table 1 for tank abbreviations 
Table 3. Transparent exopolymer particle (TEP) determination and carbon (C) content. $\delta$ : spectral slope. POC: particulate organic carbon. PON: particulate organic nitrogen. See Table 1 for tank abbreviations. Grey background: identical experimental conditions for Expts 1 and 2

\begin{tabular}{|c|c|c|c|c|c|c|c|c|}
\hline \multirow[b]{2}{*}{ Expt 1} & \multicolumn{8}{|c|}{ Tank } \\
\hline & So & T0 & $\mathbf{S 4}$ & T4 & S8 & T8 & S16 & T16 \\
\hline Average TEP number $\left(\times 10^{6} \mathrm{l}^{-1}\right)$ & 50.2 & 56.1 & 63.8 & 83.1 & 94.4 & 81 & 79.7 & 105.1 \\
\hline Max. TEP number $\left(\times 10^{6} \mathrm{l}^{-1}\right)$ & 94.3 & 134.9 & 118.6 & 124.8 & 137.2 & 143.1 & 112.4 & 389.0 \\
\hline Average TEP-C content $\left(\mu \mathrm{C} \mathrm{C}^{-1}\right)$ & 312.0 & 384.0 & 319.2 & 536.4 & 625.2 & 596.4 & 608.4 & 1057.2 \\
\hline Max. TEP-C content $\left(\mu \mathrm{g} \mathrm{C}^{-1}\right)$ & 542.4 & 1068.0 & 619.2 & 1039.2 & 1094.4 & 973.2 & 850.8 & 5259.6 \\
\hline Lower $\delta$ value & -3.03 & -3.21 & -3.13 & -3.22 & -3.02 & -2.91 & -3.01 & -3.03 \\
\hline Max. $\delta$ value & -2.49 & -2.51 & -2.26 & -2.49 & -2.54 & -2.37 & -2.56 & -2.61 \\
\hline Max. POC $(\mu \mathrm{M})$ & 38.3 & 29.1 & 42.5 & 51.5 & 54.6 & 73.6 & 140.2 & 160.9 \\
\hline Max. PON $(\mu \mathrm{M})$ & 4.2 & 3.8 & 5.9 & 7.2 & 9.1 & 9.1 & 12.1 & 13.3 \\
\hline Expt 2 & B & $\mathbf{T}$ & $\mathbf{Z}$ & $\mathbf{T Z}$ & Si & TSi & ZSi & TZSi \\
\hline Average TEP number $\left(\times 10^{6} \mathrm{l}^{-1}\right)$ & 32.7 & 32.1 & 25.0 & 19.2 & 43.2 & 46.0 & 28.6 & 45.8 \\
\hline Max. TEP number $\left(\times 10^{6} \mathrm{I}^{-1}\right)$ & 64.4 & 54.1 & 35.8 & 27.8 & 83.0 & 77.7 & 41.3 & 82.7 \\
\hline Average TEP-C content $\left(\mu g \mathrm{C}^{-1}\right)$ & 562.0 & 569.0 & 405.6 & 405.6 & 670.2 & 981.4 & 438.2 & 814.4 \\
\hline Max. TEP-C content $\left(\mu \mathrm{g} \mathrm{Cl}^{-1}\right)$ & 1538.3 & 1247.6 & 1031.4 & 1031.4 & 1284.1 & 2156.4 & 1043.6 & 1968.5 \\
\hline Lower $\delta$ value & -3.11 & -3.24 & -2.93 & -2.49 & -3.29 & -3.14 & -3.13 & -3.12 \\
\hline Max. $\delta$ value & -2.74 & -2.45 & -2.14 & -2.00 & -2.52 & -1.99 & -1.90 & -1.69 \\
\hline TEP increase rate $\left(\mathrm{d}^{-1}\right)$ & 0.44 & 0.49 & 0.37 & 0.37 & 0.48 & 0.71 & 0.44 & 0.60 \\
\hline Chl a growth rate $\left(\mu, d^{-1}\right)$ & 0.62 & 0.53 & 0.53 & 0.66 & 0.51 & 0.63 & 0.51 & 0.70 \\
\hline
\end{tabular}

plankton exponential phase, with an overall 2- to 19 -fold increase in the amount of TEP with a decrease in chl a concentration. Little difference between still and turbulent tanks was observed (Fig. 2).

When all data were pooled together, TEP abundance was not directly affected by turbulence and nutrients (ANCOVA, $\mathrm{n}=54, \mathrm{p}=0.40$ and 0.28 respectively). However, during the exponential phase of phytoplankton, the kinetics of TEP formation followed the initial input of nutrients (ANCOVA, $n=24, p=0.008$ ). Before nutrient addition, TEP abundance was $6.3 \times 10^{6} \mathrm{l}^{-1}$, then TEP concentration increased from $6 \times 10^{6}$ to $40 \times$ $10^{6} \mathrm{l}^{-1}$ in $1 \mathrm{~d}$ in Tanks S8, T8, S16, and T16; it took $2 \mathrm{~d}$ in Tanks $\mathrm{S} 4$ and $\mathrm{T} 4$ to reach this concentration and $3 \mathrm{~d}$ in tanks with no addition of nutrients ( $\mathrm{S} 0$ and $\mathrm{T} 0$ ). Subsequently, TEP concentration varied from $50 \times 10^{6}$ to $135 \times 10^{6} 1^{-1}$ in tanks with no addition of nutrients. In tanks with nutrients added, TEP concentration varied from $60 \times 10^{6}$ to $143 \times 10^{6} \mathrm{I}^{-1}$, except in T16 tanks where a maximum concentration of $389 \times 10^{6} \mathrm{l}^{-1}$ was observed on Day 12 (Table 3 ). The calculated production rates of TEP $\left(\mathrm{d}^{-1}\right)$ and chl a growth rates $\left(\mu, \mathrm{d}^{-1}\right)$ during the exponential phase of phytoplankton also increased with nutrient dose (Fig. 3). The highest TEP production rates $\left(0.80 \pm 0.12 \mathrm{~d}^{-1}\right)$ were reached in $\mathrm{S} 8$ treatments (Fig. 3). In tanks where no nutrients were added, the TEP production rate was $0.50 \pm 0.09 \mathrm{~d}^{-1}$, while chl a decreased, leading to negative $\mu$ values. The net apparent increase rates of TEP were closely linked to chl a growth rates $(y=0.33 x+0.59, r=0.89)$ (Fig. 3).

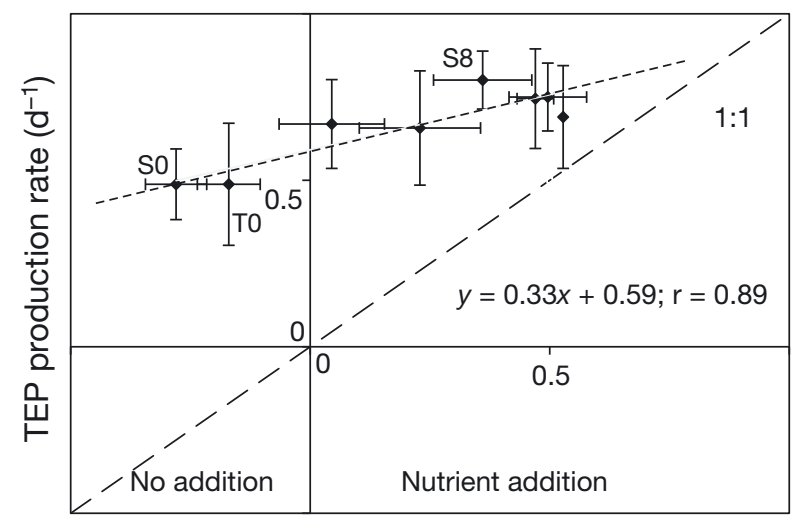

Chl a growth rate $\left(\mathrm{d}^{-1}\right)$

Fig. 3. Transparent exopolymer particles (TEP) production rate and chl a growth rates $(\mu)$ during the phytoplankton exponential phase in Expt 1. Each point corresponds to the slope $\pm \mathrm{SD}$ of the regression lines between the log of TEP concentration and time (Days 1 to 4 ) of treatment. Chl a decreased in tanks without nutrient addition (S0, T0), leading to negative $\mu$-values

\section{Expt 2}

TEP volume concentration before nutrient addition was $2.36 \mathrm{ppm}$; after addition of nutrients, in particular silicate, TEP dynamics were markedly different (Fig. 1D). In tanks not enriched with silicates, on Day 3, TEP volume concentration was $13.6 \pm 3.34 \mathrm{ppm}$, and it increased to reach on Day 6 an average of 51 and 82.5 ppm in tanks where zooplankton were present $(\mathrm{Z}$, 
TZ) and absent $(\mathrm{B}, \mathrm{T})$ respectively. In tanks enriched with silicates, TEP volume concentration reached, on Day 3, double (26 ppm) that in tanks without silicate addition, then it increased to reach on Day 5 values of $128 \mathrm{ppm}$ and $166 \mathrm{ppm}$ in turbulent tanks TSi and TZSi respectively (Fig. 1D). Initial values of $\mathrm{C}$ contained in

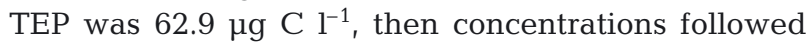
the same patterns as TEP volume, with the maximum concentration seen in turbulent tanks enriched with silicates (2156 and $1969 \mu \mathrm{C}^{-1}$ in TSi and TZSI, respectively; Table 3 ). TEP abundance before nutrient addition was $9.4 \times 10^{6} \mathrm{l}^{-1}$, and after nutrient addition TEP concentrations increased in all tanks, with maximum concentrations of $78 \times 10^{6}$ and $83 \times 10^{6} \mathrm{l}^{-1}$ in turbulent tanks enriched with silicates (TSi, TZSi), leading to a daily production rate of TEP of $0.71 \pm 0.05$ and $0.60 \pm 0.04 \mathrm{~d}^{-1}$ respectively (Table 3 ). Lower TEP concentrations were reached in $\mathrm{Z}$ and TZ tanks, with TEP production rates of $0.37 \pm 0.03$ (Table 3 ). No significant correlation was found between the net apparent increase rates of TEP and chl a growth rates $(p=0.37)$. Comparison of Si and TSi treatments with the same experimental conditions as in Expt 1 (S8 and T8; Table 3) showed that maximum TEP abundance was reached in Expt 1, while TEP volume concentration and TEP-C were higher in Expt 2, especially from Day 4 (Table 3).

\section{Size distribution}

During the 2 experiments, the size distribution of TEP followed a power-law distribution, with highly significant regression relationships $(p<0.001)$ in all treatments. The size spectrum of TEP ranged from 1.08 to $96 \mu \mathrm{m}$ ESD. The spectral slopes $(\delta=$ slope of the cumulative size distribution) were used to describe the TEP size distribution, with an increase in $\delta$ being due to an increase of the fraction of large TEP and potentially TEP aggregation. In Expt 1, the size distribution of TEP was neither influenced by turbulence nor by the level of nutrients (ANCOVA, p $=0.7$ and 0.4 respectively, $\mathrm{n}=540$ ), and the value of the slope $(\delta)$ varied from -3.22 in T4 to -2.26 in S4 (Table 3).

Fig. 4 shows for Expt 1 the average TEP volume concentration for each treatment normalized for each TEP size class $\left(\mathrm{ppm} \mathrm{m}^{-1}\right)$. The volume concentrations of small $(<3 \mu \mathrm{m})$ TEP in the total TEP pool was about $10 \%$, with few differences between treatments, except in tanks in which $16 \mu \mathrm{M}$ nitrate was added, where on Day 12 they represented $5 \%$ of total TEP. For TEP with 3 to $48 \mu \mathrm{m}$ ESD, results showed an increase in TEP volume in each size class with nutrient dose. This change was principally due to an increase in the contribution of larger TEP ( 24 to $48 \mu \mathrm{m})$ to the total TEP pool. At the beginning of the experiment they represented $12 \%$ and on Day 6

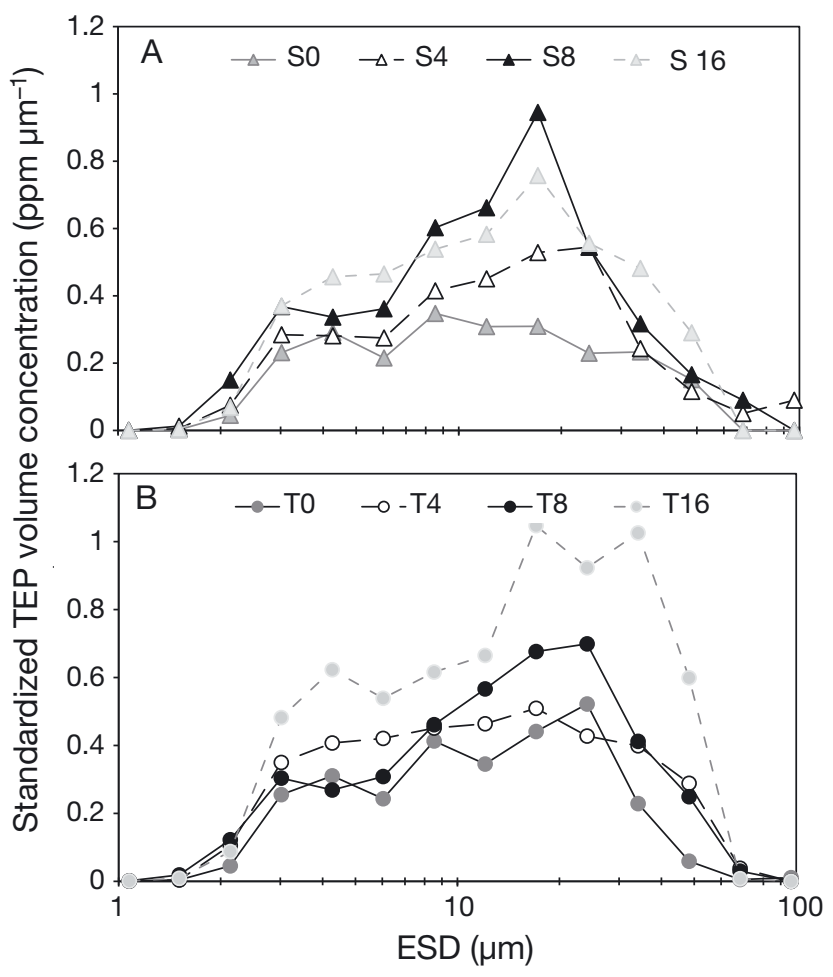

Fig. 4. Mean distribution of transparent exopolymer particles (TEP) volume concentration in each treatment during Expt 1 in (A) still and (B) turbulent tanks. Data are the average of Days 1 to 6 . The equivalent spherical diameter (ESD) is presented in log scale. The concentration of TEP (ppm) belonging to a given size class was standardized by the width of this size class

they made up 18 and $31 \%$ of the total TEP pool in still and turbulent tanks respectively. On Day 12, in still and turbulent tanks enriched with $16 \mu \mathrm{M}$ nitrate, they represented respectively 26 and $27 \%$ of total TEP. TEP of 4 to $17 \mu \mathrm{m}$ size represented an average $66 \%$. The contribution of larger TEP (>48 $\mu \mathrm{m})$ increased from $9 \%$ initially to $18 \%$ on Day 12 in T16 tanks. In still tanks, maximum TEP volume occurred in S8 tanks. In turbulent tanks, TEP volume was significantly higher in T16 tanks (ANCOVA, $\mathrm{n}=48, \mathrm{p}=0.014$ ).

During Expt 2, the slope of the TEP size distribution ranged from -3.29 to -1.69 (Table 3 ). The less negative values indicate an increase in the fraction of large particles and corresponded to tanks with the addition of silicates and the presence of zooplankton, ZSi $(\delta=-1.9$ from Day 4 to Day 6 ) and TZSi ( $\delta=-1.69$ on Day 6). In fact, while TEP size distribution was not directly affected by turbulence (ANCOVA, $\mathrm{p}=0.94, \mathrm{n}=420$ ), it seems that the presence of zooplankton and silicates significantly affected size spectra (ANCOVA, $p=0.02$, $\mathrm{n}=420$ ). Post hoc analyses showed differences between tanks; TEP were significantly smaller and more abundant in each size class in tanks with silicates and 
without zooplankton $(\mathrm{Si}, \mathrm{TSi})$ than in the other tanks $(p=0.04)$. Fig. 5 shows TEP size spectra pooled in tanks with silicates ( $\mathrm{Si}, \mathrm{TSi})$ and zooplankton and silicates $(\mathrm{Z}$, $\mathrm{TZ}, \mathrm{ZSi}, \mathrm{TZSi}$ ) from Days 4 to 6 . Regression slopes indicated that TEP were relatively smaller in tanks with the presence of silicates $(-2.66 \pm 0.01$; Fig. 5). In fact, the size class of 1 to $17 \mu \mathrm{m}$ that represented $90 \%$ of the total TEP pool at the beginning remained the most important during all of the experiment, representing 79 and $49 \%$ of total the TEP pool, respectively, on Days 4 and 6 . In tanks with the presence of zooplankton, TEP concentration was lower, with a large fraction of large particles (slope $=-2.51 \pm 0.01$; Fig. 5). The most noteworthy result was the temporal decline in the contribution of small-sized TEP and the increase in the contribution of larger TEP (Fig. 6). Initially, on Day 0, TEP 1 to $17 \mu \mathrm{m}$ in size represented an average $77 \%$ of total the TEP pool, with small differences between tanks; after the bloom, their contribution decreased, representing $26 \%$ on Day 6 . TEP of 24 to $34 \mu \mathrm{m}$ ESD increased in number up to Day 4 , representing $52 \%$ of the total TEP pool, then larger TEP $(>48 \mu \mathrm{m})$ appeared and made up $65 \%$ of total TEP in TZ and ZSi tanks.

\section{$C, N$, and P dynamics}

Fig. 7 shows changes in nitrate, POC, and PON concentrations during Expt 1. Before nutrient addition, POC and PON concentrations were 18.32 and $2.95 \mu \mathrm{M}$, respectively. In S0, T0, S4, T4, and S8 tanks, there were

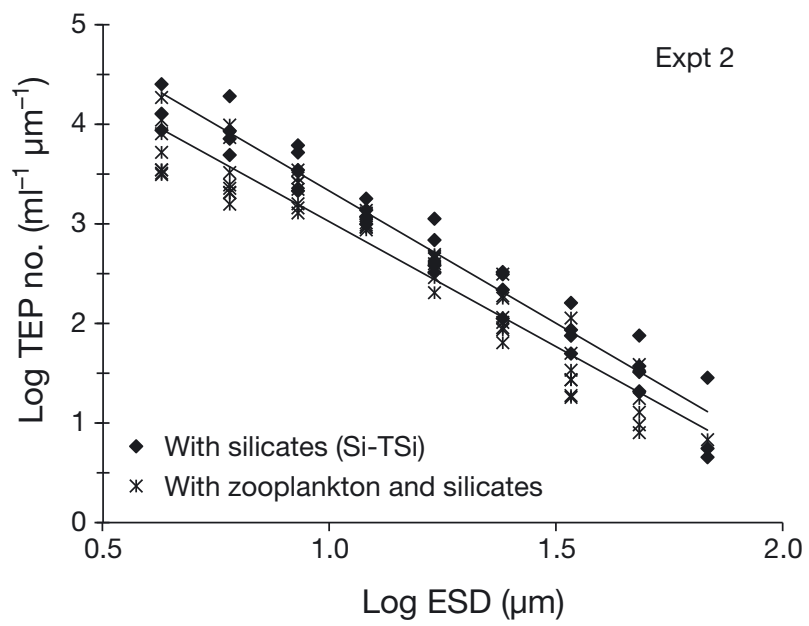

Fig. 5. Transparent exopolymer particles (TEP) number (no.) and size spectra (equivalent spherical diameter, ESD) with log-log transformation in Expt 2 pooled in tanks with silicates (Si-TSi) and zooplankton and silicates (Z, TZ, ZSi, TZSi). Regression lines (see Eq. 1) were calculated for data obtained from Days 4 to 6 . The regression slope $(\partial)$ is $-2.66 \pm 0.01$ ( $\mathrm{n}=$ $34, \mathrm{p}<0.001)$ for Si-TSi tanks and $-2.51 \pm 0.01(\mathrm{n}=61, \mathrm{p}<$ 0.001) for Z, TZ, ZSi, and TZSi tanks. See Table 1 for tank abbreviations small increases in POC and PON concentration during the experiment, with maximum concentrations reached on Day 4 in T8 tanks (54.6 and $9.1 \mu \mathrm{M}$ respectively; Table 3). The C:N ratio of POM was on average
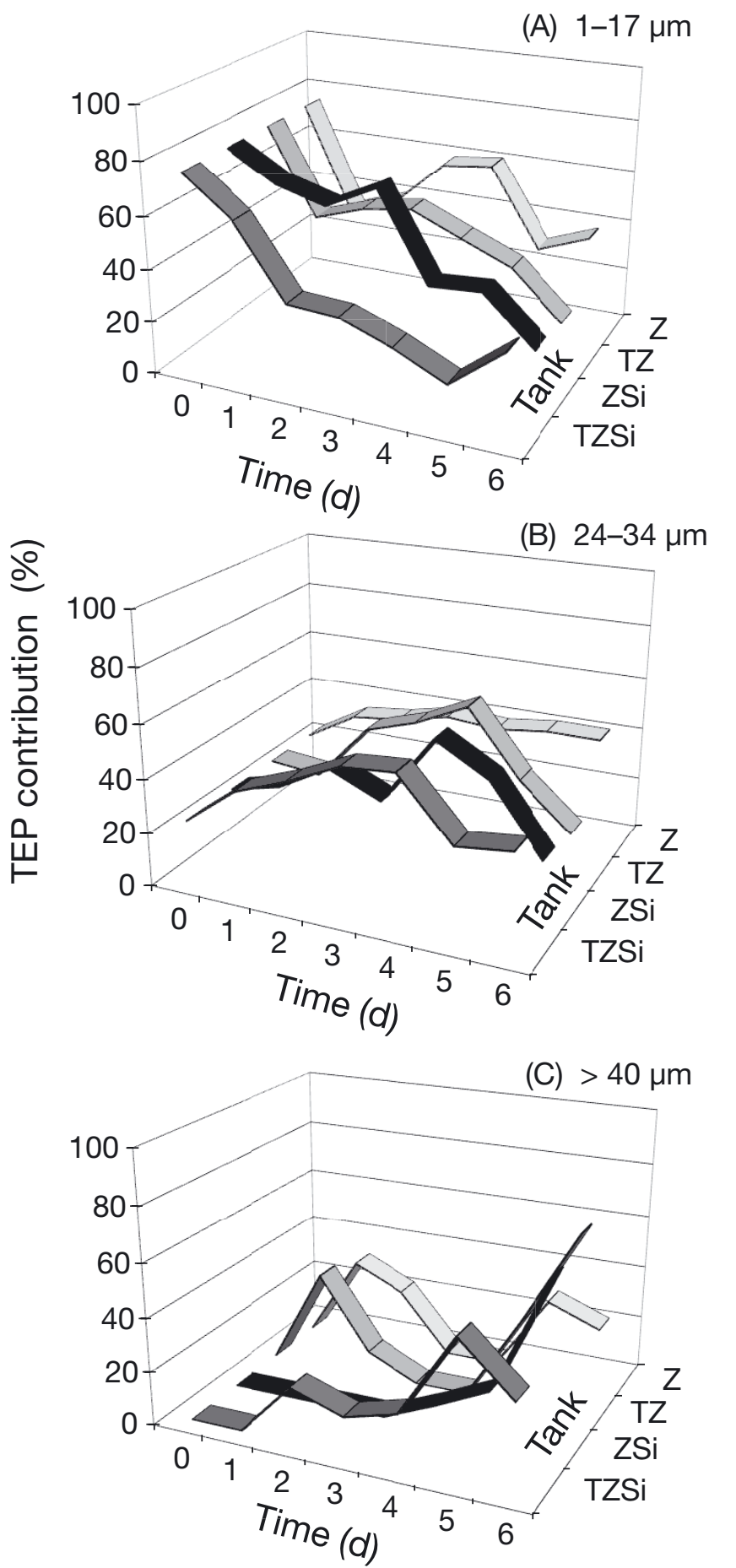

Fig. 6. Contribution of different sizes of transparent exopolymer particles (TEP) (A: 1-17 $\mu \mathrm{m}, \mathrm{B}: 24-34 \mu \mathrm{m}, \mathrm{C}:>40 \mu \mathrm{m}$ equivalent spherical diameter) to the total TEP pool in tanks with the presence of silicates and zooplankton during Expt 2. See Table 1 for tank abbreviations 

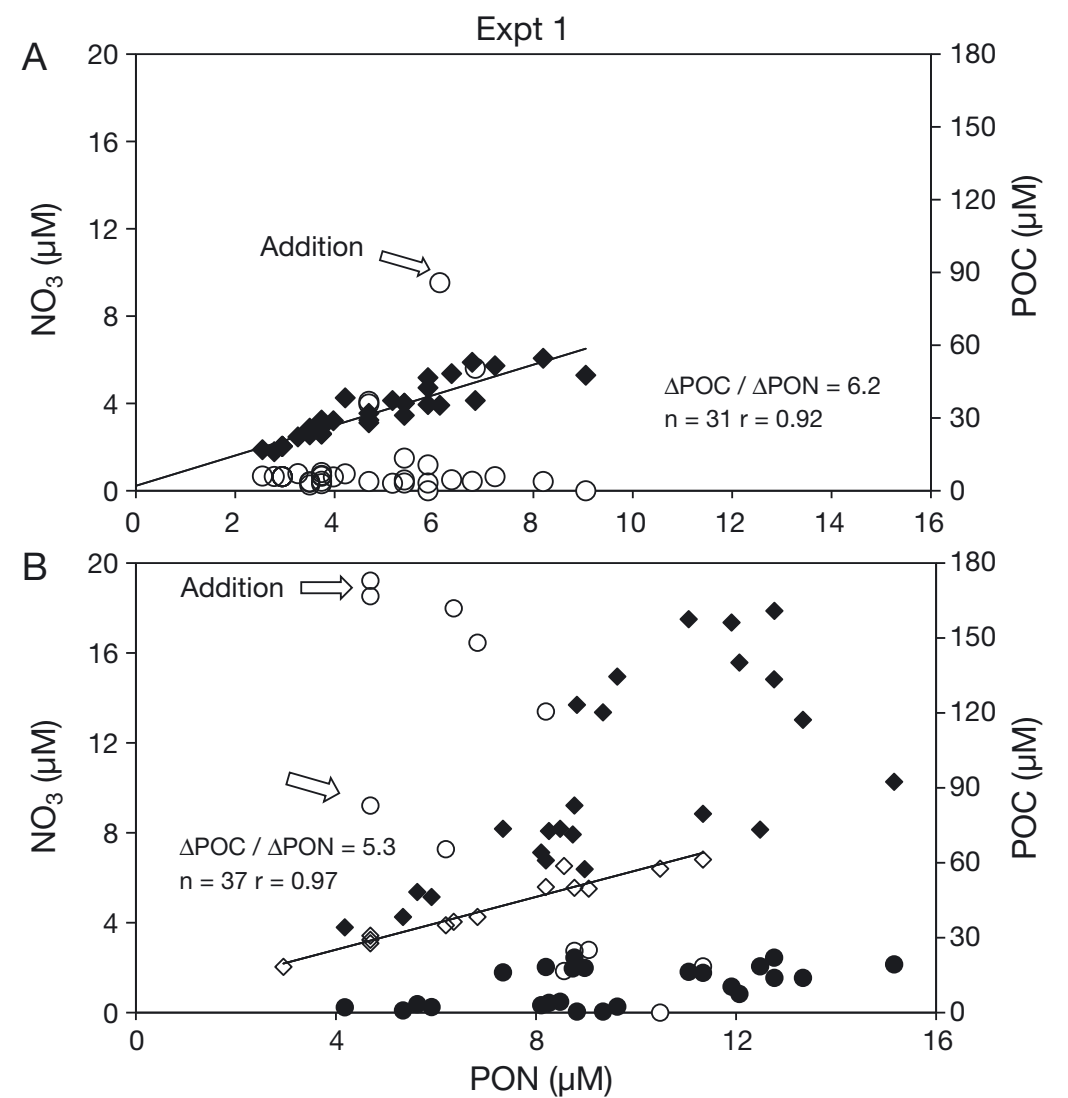

Fig. 7. Changes in nitrate, particulate organic carbon (POC), and particulate organic nitrogen (PON) during Expt 1. (A) Pooled data from S0, T0, S4, T4, and S8 Tanks; (O) nitrate and $(\diamond)$ POC. Regression was calculated from data obtained from Days 0 to 6. (B) Pooled data from T8, S16, and T16 tanks during the exponential phase $(O$, nitrate and $\diamond, P O C)$ and after nitrate depletion (๑, nitrate and $\bullet$, POC). See Table 1 for tank abbreviations

bulent tanks enriched with silicates, while for the other tanks no correlation with TEP$\mathrm{C}$ was found (Fig. 8A). The daily change in dissolved nitrate and phosphate altered the $\mathrm{N}: \mathrm{P}$ ratios from initially 16 to $<1$ at the end of the study. Low values of the $\mathrm{N}$ :P ratio were coincident with high TEP concentrations (Fig. 8B).

\section{DISCUSSION}

The nutrients added at the onset of Expt 1 were supposed to promote the development of a diatom bloom; however, a large initial biomass of small autotrophs including coccolithophorids (Emiliania huxleyi) and Synechococcus-like cyanobacteria took up most of the nutrients. E. huxleyi is a bloom-forming coccolithophorid that in late spring-early summer can reach concentrations of $5 \times 10^{6}$ to $\sim 10^{8}$ cells $\mathrm{l}^{-1}$ (Egge \& Heimdal 1994, Brussaard et al. 1996). This was confirmed by the high fraction of small cells present at the beginning of the experiment and by the low chl a peaks achieved in the tanks. Diatoms did not develop quickly and appeared in significant numbers only by Day 4. During Expt 2, there was an increase in the contribution of diatoms to the total phytoplankton biomass. In both experiments, the higher TEP concentra-

6.2, very close to the expected Redfield ratio of 6.6 (Fig. 7A). In T8, S16, and T16 tanks, tight co-variation of POC and PON occurred as long as nutrients were replete; on Day 4, POC and PON average concentrations were 59.2 and $10.1 \mu \mathrm{M}$ respectively. The C:N ratio was on average 6.0 (Fig. 7B). By Day 5, at the time of nutrient exhaustion, whereas PON increased slightly, POC concentration more than doubled (140 and $161 \mu \mathrm{M}$ respectively in S16 and T16 tanks; Table 3), leading to a significant increase in the C:N ratio of POM (14.3 on Day 11 in $\mathrm{T} 16$ tanks). The increase in the $\mathrm{C}: \mathrm{N}$ ratio after the bloom was correlated with TEP formation $(r=0.76, p=0.028, n$ $=8$ ). While no correlation was found between TEP and POC in S0, T0, S4, T4, and S8 tanks, in tanks with higher nutrient concentration (T8, S16, T16), the increase in TEP concentration was positively correlated with POC $(y=$ $0.51 x+15.11, \mathrm{r}=0.6, \mathrm{n}=32, \mathrm{p}<0.001)$. The contribution of TEP-C to POC in these tanks was 50\% (data from Day 12 in T16 tanks was removed from calculation as the TEP-C value exceeded POC values by 2.8). In Expt 2, the increase in the POC:PON ratio was positively correlated with the increase in TEP volume concentrations in tur- tion was reached after the bloom in turbulent tanks enriched with the maximum level of nutrients. However, when comparing Expts 1 and 2, we observed that with the same nutrient dose (tanks enriched with $8 \mu \mathrm{M}$ of nitrate and $16 \mu \mathrm{m}$ of silicate), higher TEP concentrations were generated in Expt 2. In Expt 1, TEP was principally produced by small phytoplankton, including E. huxleyi, while in Expt 2 the increase in diatom concentration supported higher TEP production. In marine waters and in experimental studies, diatoms have been found to be the main producers of TEP (Kiørboe \& Hansen 1993, Passow \& Alldredge 1994, Prieto et al. 2002). Small-scale turbulence that has little effect on the nutrient flux to small phytoplankton could however favor large cells in the competition for nutrients (Karp-Boss et al. 1996). While in Expt 1, turbulence did not affect TEP production, it is likely that in Expt 2, both turbulence and silicate addition resulted in high TEP production, as these factors stimulated diatom growth. This stresses the importance of initial phytoplankton composition and turbulence in TEP dynamics. 

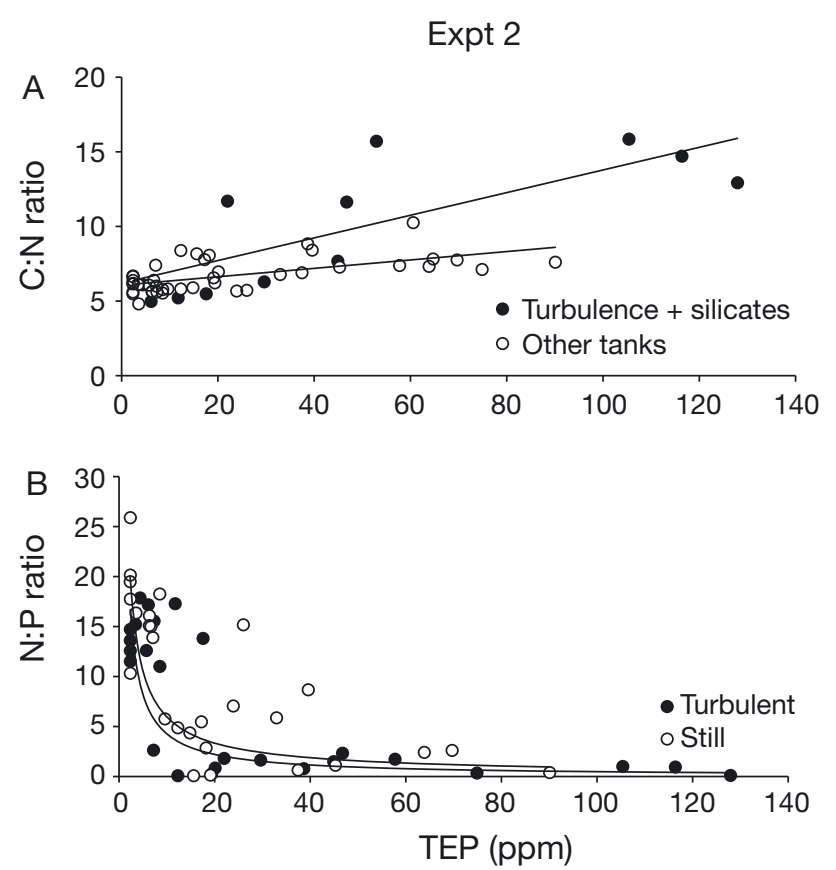

Fig. 8. (A) Correlation between the C:N ratio of particulate organic matter and transparent exopolymer particles (TEP) concentration (ppm) during Expt 2 in turbulent tanks enriched with silicates $(\bullet)(y=0.08 x+6.20 ; \mathrm{r}=0.8 ; \mathrm{n}=14 ; \mathrm{p}<$ $0.001)$ and in the other tanks (O) $(y=0.03 x+6.06 ; \mathrm{r}=0.6 ; \mathrm{n}=$ $42 ; \mathrm{p}<0.05)$. (B) $\mathrm{N}: \mathrm{P}$ ratio versus TEP concentration (ppm) in turbulent tanks $(\bullet)\left(y=37.63 x^{-0.95} ; \mathrm{r}=0.72 ; \mathrm{n}=41 ; \mathrm{p}<0.001\right)$ and in still tanks $(\mathrm{O})\left(\mathrm{y}=40.31 \mathrm{x}^{-0.83} ; \mathrm{r}=0.61 ; \mathrm{n}=41, \mathrm{p}<0.05\right)$

\section{TEP dynamics under a gradient of nutrients}

The increase in nutrient levels yielded higher net increase rates of TEP and accelerated the kinetics of TEP formation in turbulent tanks (Fig. 2). This suggests that TEP consists of fresh organic material, derived from active phytoplankton cells exuding the precursors. The combination of nutrients and turbulence, by increasing the nutrient flux to cells, induces an increase in phytoplankton growth rates (Karp-Boss et al. 1996, Peters et al. 2006). It is likely that in the present study, the presence of turbulence increased TEP concentration and subsequently promoted TEP aggregation. This was shown by the increase in the contribution of larger TEP (27\% of total TEP; Fig. 4) in turbulent tanks and by the very much higher TEP concentration in T16 tanks on Day 12. Moreover, the high stickiness coefficient of TEP (e.g. Dam \& Drapeau 1995), even if it was not measured in the present study, might facilitate this process. Our data also suggests that TEP production is not necessarily linked to nutrient availability; while higher nutrient conditions enhanced the absolute concentration of TEP, the relative quantity of TEP produced to biomass is likely to be lower (Fig. 3). Increases in TEP concentration after phytoplankton blooms have also been observed in other experimental systems and have been attributed to nutrient limitation (Corzo et al. 2000, Engel 2000). Corzo et al. (2000) showed a doubling effect of $\mathrm{N}$ availability during culture experiments with Chaetoceros calcitrans. While maximum phytoplankton biomass and TEP concentrations were reached at high $\mathrm{N}$ supply, the production of TEP per phytoplankton biomass during the exponential phase was higher in N-limited culture. This suggests that TEP formation is rather a function of the physiological state of cells than of the standing stock of phytoplankton (Schuster \& Herndl 1995, Maldonado et al. 2001). The production of exudates is known to be higher under nutrient stress (Underwood et al. 2004). In some cases, a P limitation may stimulate more excretion and therefore induce higher extracellular polysaccharides production by the cells than an $\mathrm{N}$ limitation (Myklestad 1977, Obernosterer \& Herndl 1995). This could explain the high amount of TEP per phytoplankton biomass observed in the present study in tanks without the addition of nutrients (S0, T0). In these tanks, limited nitrate and/or phosphate conditions prevailed from the beginning of the experiment. It is likely that this limitation increased the relative TEP concentration. When light is not limiting, the availability of nutrients may limit phytoplankton biomass but not photosynthesis, and as a consequence the $\mathrm{C}$ produced by phytoplankton is exuded as extracellular carbohydrates. However, the linear relationship obtained by Claquin et al. (2008) between TEP production and photosynthetic activity in diatom cultures indicated that $\mathrm{C}$ excretion was not simply due to an overflow of $\mathrm{C}$ resulting from unbalanced growth, but to a balance between production and excretion of $\mathrm{C}$. These considerations suggest that TEP produced per unit of $\mathrm{N}$ or $\mathrm{P}$ might vary with species and across systems.

\section{Effect of nutrients and the presence of zooplankton on TEP size distribution}

The exponent $\delta$ of the size-frequency distribution of TEP can be used as an indicator of the degree of TEP aggregation. For example, Passow \& Alldredge (1994) showed that at the end of a diatom bloom, $\delta$ is around -2 or lower, indicating a reduction in the fraction of small particles as the aggregation dominates TEP size distribution. During Expt 1, $\delta$ corresponded to the type of distribution observed by Passow \& Alldredge (1994) when diatom concentrations were low and never dominating. Indeed, the contribution of small and medium particles was relatively more important than larger ones. However, the increase in TEP volume with nutrient dose in almost all size classes of TEP, in particular with turbulence, suggests that the interaction of nutrient availabil- 
ity and turbulence could alter the size distributions of TEP. This was also seen in Expt 2; the lower $\delta$ observed from Day 4 in tanks with zooplankton and silicates indicated that larger TEP dominate the size distribution. Beauvais et al. (2006) showed that the size distribution of TEP of size 2 to $40 \mu \mathrm{m}$ was not influenced by turbulence intensity, while a higher turbulence level influenced aggregation of larger TEP $(>40 \mu \mathrm{m})$. In the present study, turbulence did not directly affect the size distribution of TEP; however, aggregation of larger TEP seems to be favored by a combined effect of silicates and turbulence that stimulated diatom growth. It has been reported that zooplankton activity could affect the size distributions of TEP by mechanical disruption or ingestion (Passow \& Alldredge 1999, Dilling \& Alldredge 2000). Feeding activities of zooplankton, in particular copepods and euphausiids, may contribute to the formation of larger TEP (Prieto et al. 2001). Hence, in the present study it is likely that zooplankton reduced TEP concentration by increasing aggregation of larger TEP. However, we cannot assert a possible contribution to the formation or ingestion of TEP as no grazing experiment was done. The advantage of the experimental design chosen for the present study was the possibility of comparing the effects of a high number of experimental variables; however, the limited number of replicates reduced the power of the analyses. By exploring combinations of various treatments, we were able to gain an ecological understanding of TEP dynamics.

\section{C dynamics}

We observed that the elemental composition of POM differed from the Redfield ratio of 6.6 by enrichment in $\mathrm{C}$ and a depletion of $\mathrm{N}$ relative to $\mathrm{P}$. The magnitude of this variation depends on the inorganic nutrient conditions associated with several biotic enhancements, including phytoplankton growth, bacterial recycling, and possibly changes in protozoan grazing. The decoupling of $\mathrm{C}$ and $\mathrm{N}$ dynamics that occurred during the post-bloom in enriched nutrient conditions was probably due to the production of TEP, with a direct relationship between TEP-C and POC. Engel et al. (2002) estimated in mesocosm experiments that TEP production could explain $40 \%$ of decreases in dissolved inorganic $\mathrm{C}$ and an average increase in POC concentration of $35 \%$ (Engel et al. 2004). In the present study, the contribution of TEP-C to POC reached $~ 50 \%$ in higher nutrient conditions. Even if this value seems to be overestimated, and sometimes exceeded the value of POC, we inferred that the increase in the $\mathrm{C}: \mathrm{N}$ ratio of $\mathrm{POM}$ is explained in part by the formation of TEP rich in $C$, with a large flow of $C$ channeled toward the TEP pool in turbulent tanks. Engel \& Passow (2001) reported
TEP-C values for the northern Adriatic Sea representing $103 \%$ of measured POC. According to those authors, this high value is probably because some variable fraction of TEP-C is measured as DOC, as TEP cannot be retained quantitatively in GF/F filters. Our calculations and conversion factors for TEP-C concentration come from the only available theoretical sizerelationships determined from TEP produced in the laboratory from diatom cultures (Mari 1999). In Expt 1, small cells other than diatoms comprised $>50 \%$ of the phytoplanktonic biomass (Table 2). Assuming that the production of exudates is likely to be species-specific (Penna et al. 1999), the C content of TEP changes between species and the relationship Eq. (2) may therefore be inaccurate for estimating TEP production by groups other than diatoms. Additional studies are necessary in order to estimate the $\mathrm{C}$ conversion factor for TEP for other phytoplankton groups producing TEP. Another possible explanation for the higher contribution of TEP to POC is that POC was underestimated due to losses by sedimentation. TEP volume concentrations in turbulent tanks enriched with silicate were also positively correlated to the POC:PON ratio and negatively to the $\mathrm{N}: \mathrm{P}$ ratio. The ratio of $\mathrm{C}$ to $\mathrm{P}$ in POM has been found to be higher under turbulence treatments (Maar et al. 2002). This means that the increase in organic $\mathrm{C}$ per unit of nutrient consumed is higher in turbulent than in still conditions. Bacteria can also contribute to variations in the stoichiometry of organic matter by secreting polysaccharides as free exopolymers (Decho 1990) or by the mineralization of aggregates (Smith et al. 1992). It was shown in mesocosm experiments that bacteria contribute only 1 to $3 \%$ of TEP production (Stoderegger \& Herndl 1999). Considering these low values we hypothesize that the main source of TEP in our mesocosms was the exudation of precursors by phytoplankton rather than by bacteria. Even if it was not measured in this experiment, bacteria degradation may be an important loss process for TEP. The high hydrolytic enzyme activity of bacteria in aggregates, including TEP, suggests their degradation and/or consumption by bacteria (Smith et al. 1995). Part of the carbohydrates that formed TEP could be used as substrates by the bacteria present in our experiment, removing organic $C$ and regulating the $C: N$ ratio of total organic matter. Indeed, at the end of the 2 experiments, large concentrations of bacteria were observed in the tanks enriched with $16 \mu \mathrm{mol}$ of nitrates (ca. $3.0 \times 10^{6}$ on Days 7 and 8; F. Peters unpubl. data). In a previous mesocosm study, Pedrotti et al. (2009) showed that bacteria largely colonize TEP. The rate of bacteria colonization was linked to TEP formation after the diatom bloom and was significantly higher in enriched turbulent tanks. Further investigations concerning species-specific phytoplankton activity and 
their $\mathrm{C}$ excretion will be important to better determine the dynamics of TEP and therefore to elucidate essential feedbacks in the $\mathrm{C}$ cycle.

\section{CONCLUSIONS}

The present study showed the effect of important bulk ecosystem properties on TEP production. TEP were influenced by nutrient additions and by effects of small-scale turbulence. Treatments with high concentrations of nutrients increased the kinetics of TEP formation and the net apparent production rates, although the highest TEP production was observed in post-bloom situations when the nutrients were already exhausted. Both turbulence and silicate addition resulted in high TEP production, as these factors favor autotrophic production. The contribution of large TEP increased with nutrient dose and in the presence of turbulence. The presence of zooplankton changed the size distribution of TEP and lowered the concentration of TEP as predicted, presumably by grazing on TEP or phytoplankton. Because TEP formation influences the stoichiometry of POM, the fate of phytoplankton blooms, and aggregation mechanisms, accurate information about this highly dynamic organic $\mathrm{C}$ pool is needed to elucidate processes that drive biogeochemical cycles. The present study contributes to the knowledge of how TEP dynamics affect $C$ fluxes in a system modulated by interaction between turbulence and nutrients, and how these dynamics vary depending on the composition of plankton assemblages. The significance of TEP for the vertical flux of $\mathrm{C}$ will depend on the relative importance of each of the processes we have discussed (i.e. aggregation-sedimentation, bacterial mineralization, consumption, grazing).

Acknowledgments. This study was supported by EU project NTAP (EVK3-CT-2000-00022). Access to the Espeland Marine Biological Station of the Bergen Marine Food Chain Research Infrastructure was possible through Contract No. HPRI-CT-1999-00056 of the Improving Human Potential Programme of the European Union. F.P. held a Ramon y Cajal contract. We thank the reviewers for their comments that helped improve the manuscript. J. Dolan was of great help editing the English. J. E. Stiansen and F.P. designed the turbulence system. Turbulence measurements were done by J. E. Stiansen.

\section{LITERATURE CITED}

Alldredge AL, Passow U, Logan BE (1993) The abundance and significance of a class of large, transparent organic particles in the ocean. Deep-Sea Res I 40:1131-1140

> Beauvais S, Pedrotti ML, Villa E, Lemée R (2003) Transparent exopolymer particle (TEP) dynamics in relation to trophic and hydrological conditions in the NW Mediterranean. Mar Ecol Prog Ser 262:97-109
Beauvais S, Pedrotti ML, Egge J, Iversen K, Marrasé C (2006) Effects of turbulence on TEP dynamics under contrasting nutrient conditions: implications for aggregation and sedimentation processes. Mar Ecol Prog Ser 323:47-57

> Berman T, Viner-Mozzini Y (2001) Abundance and characteristics of polysaccharide and proteinaceous particles in Lake Kinneret. Aquat Microb Ecol 24:255-264

Brussaard CPD, Kempers RS, Kop AJ, Riegman R, Heldal M (1996) Virus-like particles in a summer bloom of Emiliana huxleyi in the North Sea. Aquat Microb Ecol 10:105-113

> Carrias JF, Serre JP, Sime-Ngando T, Amblard C (2002) Distribution, size, and bacterial colonization of pico- and nano-detrital organic particles (DOP) in two lakes of different trophic status. Limnol Oceanogr 47:1202-1209

Claquin P, Probert I, Lefebvre S, Véron B (2008) Effects of temperature on photosynthetic parameters and TEP production in eight species of marine microalgae. Aquat Microb Ecol 51:1-11

Corzo A, Morillo JA, Rodriguez S (2000) Production of transparent exopolymer particles (TEP) in cultures of Chaetoceros calcitrans under nitrogen limitation. Aquat Microb Ecol 23:63-72

$>$ Dam HG, Drapeau DT (1995) Coagulation efficiency, organicmatter glues, and the dynamics of particles during a phytoplankton bloom in a mesocosm study. Deep-Sea Res II 42:111-123

Decho AW (1990) Microbial exopolymer secretions in ocean environments: their role(s) in food webs and marine processes. Oceanogr Mar Biol Annu Rev 28:73-153

Dilling L, Alldredge AL (2000) Fragmentation of marine snow by swimming macrozooplankton: a new process impacting carbon cycling in the sea. Deep-Sea Res I 47: $1227-1245$

Egge JK, Heimdal BR (1994) Blooms of phytoplankton including Emiliana huxleyi (Haptophyta). Effects of nutrient supply in different N:P ratios. Sarsia 79:333-348

Engel A (2000) The role of transparent exopolymer particles (TEP) in the increase in apparent particle stickiness during the decline of a diatom bloom. J Plankton Res 22:485-497

Engel A, Passow U (2001) Carbon and nitrogen content of transparent exopolymeric particles (TEP) in relation to their Alcian Blue adsorption. Mar Ecol Prog Ser 219:1-10

Engel A, Goldthwait S, Passow A, Alldredge A (2002) Temporal decoupling of carbon and nitrogen dynamics in a mesocosm diatom bloom. Limnol Oceanogr 47:753-761

Engel A, Delille B, Jacquet S, Riebesell U, Rochelle-Newall E, Terbrüggen A, Zondervan I (2004) Transparent exopolymer particles and dissolved organic carbon production by Emiliania huxleyi exposed to different $\mathrm{CO}_{2}$ concentrations: a mesocosm experiment. Aquat Microb Ecol 34: 93-104

Grasshoff K, Kremling K, Ehrhardt M (1999) Methods of seawater analysis. Wiley-VCH, Weinheim

Grossart HP, Simon M (1997) Formation of macroscopic organic aggregates (lake snow) in a large lake: the significance of transparent exopolymer particles, phytoplankton, and zooplankton. Limnol Oceanogr 42:1651-1659

Karp-Boss L, Boss E, Jumars PA (1996) Nutrient fluxes toplanktonic osmotrophs in the presence of fluid motion. Oceanogr Mar Biol Annu Rev 34:71-107

Kiørboe T (1993) Turbulence, phytoplankton cell size, and the structure of pelagic food webs. Adv Mar Biol 29:1-72

- Kiørboe T, Hansen LS (1993) Phytoplankton aggregate formation: observations of patterns and mechanisms of cell sticking and the significance of exopolymeric material. J Plankton Res 15:993-1018

> Logan BE, Passow U, Alldredge AL, Grossar HP, Simon M (1995) Rapid formation and sedimentation of large aggre- 
gates is predictable from coagulation rates (half-lives) of transparent exopolymer particles (TEP). Deep-Sea Res II 42:203-214

Maar M, Arin L, Simo R, Sala MM, Peters F, Marrasé C (2002) Combined effects of nutrients and small-scale turbulence in a microcosm experiment. II. Dynamics of organic matter and phosphorus. Aquat Microb Ecol 29:63-72

MacKenzie BR, Kiørboe T (1995) Encounter rates and swimming behaviour of pause-travel and cruise larval fish predators in calm and turbulent laboratory environments. Limnol Oceanogr 40:1278-1289

Maldonado MT, Boyd PW, LaRoche JL, Strzepek R and others (2001) Iron uptake and physiological response of phytoplankton during a mesoscale Southern Ocean iron enrichment. Limnol Oceanogr 46:1802-1808

> Mari X (1999) Carbon content and C:N ratio of transparent exopolymeric particles (TEP) produced by bubbling exudates of diatoms. Mar Ecol Prog Ser 183:59-71

Mari X, Beauvais S, Lemée R, Pedrotti ML (2001) Non-Redfield C:N ratio of transparent exopolymeric particles in the northwestern Mediterranean Sea. Limnol Oceanogr 46: 1831-1836

Mari X, Rassoulzadegan F, Brussaard CPD, Wassmann P (2005) Dynamics of transparent exopolymeric particles (TEP) production by Phaeocystis globosa under N- or P-limitation: a controlling factor of the retention/export balance? Harmful Algae 4:895-914

McCave IN (1984) Size spectra and aggregation of suspended particles in the deep ocean. Deep-Sea Res A 31:329-352

> Moeseneder MM, Herndl GJ (1995) Influence of turbulence on bacterial production in the sea. Limnol Oceanogr 40:1466-1473

Myklestad S (1977) Production of carbohydrates by marine planktonic diatoms. II. Influence of the N:P ratio in the growth medium on the assimilation ratio, growth rate, and production of cellular and extracellular carbohydrates by Chaetoceros affinis var. willei (Gran) Hustedt and Skeletonema costatum (Grev.) Cleve. J Exp Mar Biol Ecol 29: 161-179

> Obernosterer I, Herndl GJ (1995) Phytoplankton extracellular release and bacterial growth: dependence on the inorganic N:P ratio. Mar Ecol Prog Ser 116:247-257

Parsons TR, Maita Y, Lalli CM (1984) A manual of chemical and biological methods for sea water analysis. Pergamon Press, Oxford

Passow U (2000) Formation of transparent exopolymeric particles, TEP, from dissolved precursor material. Mar Ecol Prog Ser 192:1-11

Passow U (2002) Production of transparent exopolymeric particles (TEP) by phyto- and bacterioplankton. Mar Ecol Prog Ser 236:1-12

Passow U, Alldredge AL (1994) Distribution, size and bacterial colonization of transparent exopolymer particles (TEP) in the ocean. Mar Ecol Prog Ser 113:185-198

Passow U, Alldredge A (1995a) Aggregation of diatoms bloom in mecocosm: the role of transparent exopolymer particles (TEP). Deep-Sea Res II 42:99-109

> Passow U, Alldredge A (1995b) A dye-binding assay for the spectrophotometric measurement of transparent exopolymer particles (TEP). Limnol Oceanogr 40:1326-1335

Passow U, Alldredge AL (1999) Do transparent exopolymer particles (TEP) inhibit grazing by the euphausiid Euphausia pacifica? J Plankton Res 21:2203-2217

Passow U, Shipe RF, Murray A, Pak DK, Brzezinski MA, Alldredge A (2001) The origin of transparent exopolymeric particles (TEP) and their role in the sedimentation of particulate matter. Cont Shelf Res 21:327-346

Pedrotti ML, Beauvais S, Keros ME, Iversen K, Peters F (2009)
Bacterial colonization of transparent exopolimeric particles (TEP) in mesocosms under different trophic conditions and turbulence intensities. Aquat Microb Ecol 55: 301-312

Penna A, Berluti S, Penna N, Magnani M (1999) Influence of nutrient ratios on the in vitro extracellular polysaccharide production by marine diatoms from the Adriatic Sea. J Plankton Res 21:1681-1690

Peters F, Marrasé C (2000) Effects of turbulence on plankton: an overview of experimental evidence and some theoretical considerations. Mar Ecol Prog Ser 205:291-306

> Peters F, Marrasé C, Havskum H, Rassoulzadegan F, Dolan J, Alcaraz M, Gasol JM (2002) Turbulence and the microbial food web: effects on bacterial losses to predation and on community structure. J Plankton Res 24:321-331

Peters F, Arin L, Marrasé C, Berdalet E, Sala MM (2006) Effects of small-scale turbulence on the growth of two diatoms of different size in a phosphorus-limited medium. J Mar Syst 61:134-148

Prieto L, Sommer F, Stibor H, Koeve W (2001) Effects of planktonic copepods on transparent exopolymeric particles (TEP) abundance and size spectra. J Plankton Res 23: 515-525

> Prieto L, Ruiz J, Echevarria F, Garcia CM and others (2002) Scales and processes in the aggregation of diatom blooms: high time resolution and wide size range records in a mesocosm study. Deep-Sea Res I 49:1233-1253

Prieto L, Navarro G, Cozar A, Echevarria F, Garcia CM (2006) Distribution of TEP in the euphotic and upper mesopelagic zones of the southern Iberian coasts. Deep-Sea Res II 53: 1314-1328

- Radic T, Kraus R, Fuks D, Radic J, Pecar O (2005) Transparent exopolymeric particles' distribution in the northern Adriatic and their relation to microphytoplankton biomass and composition. Sci Total Environ 353:151-161

Reigstad M, Wassmann P, Ratkova T, Arashkevich E, Pasternak A, Øygarden S (2000) Comparison of the springtime vertical export of biogenic matter in three northern Norwegian fjords. Mar Ecol Prog Ser 201:73-89

> Savidge G (1981) Studies of the effects of small-scale turbulence on phytoplankton. J Mar Biol Assoc UK 61:477-488

Schuster S, Herndl GJ (1995) Formation and significance of transparent exopolymeric particles in the northern Adriatic Sea. Mar Ecol Prog Ser 124:227-236

Sheldon RW, Prakash A, Sutcliffe WH Jr (1972) The size distribution of particles in the ocean. Limnol Oceanogr 17: $327-340$

Smith DC, Simon M, Alldredge AL, Azam F (1992) Intense hydrolytic enzyme activity on marine aggregates and implications for rapid particle dissolution. Nature 359: 139-141

Smith DC, Steward GF, Long RA, Azam F (1995) Bacterial mediation of carbon fluxes during a diatom bloom in a mesocosm. Deep-Sea Res II 42:75-97

Stiansen JE, Sundby S (2001) Improved methods for generating and estimating turbulence in tanks suitable for fish larvae experiments. Sci Mar 65:151-167

> Stoderegger KE, Herndl GJ (1999) Production of exopolymer particles by marine bacterioplankton under contrasting turbulence conditions. Mar Ecol Prog Ser 189:9-16

Strickland JDH, Parsons TR (1972) A practical handbook of seawater analysis, 2nd edn. Bull Fish Res Board Can 167

Underwood GJC, Boulcott M, Raines CA, Waldron K (2004) Environmental effects on exoplymer production by marine benthic diatoms: dynamics, changes in composition, and pathways of production. J Phycol 40:293-304

Zhou J, Mopper K, Passow U (1998) The role of surface-active carbohydrates in the formation of transparent exopolymer particles by bubble adsorption of seawater. Limnol Oceanogr 43:1860-1871 